\title{
Front Matter: Volume 9864
}

, "Front Matter: Volume 9864," Proc. SPIE 9864, Sensing for Agriculture and Food Quality and Safety VIII, 986401 (12 August 2016); doi:

$10.1117 / 12.2244372$

SDIE Event: SPIE Commercial + Scientific Sensing and Imaging, 2016, Baltimore, MD, United States 


\title{
PROCEEDINGS OF SPIE
}

\section{Sensing for Agriculture and Food Quality and Safety VIII}

\author{
Moon S. Kim \\ Kuanglin Chao \\ Bryan A. Chin \\ Editors
}

20-21 April 2016

Baltimore, Maryland, United States

Sponsored and Published by

SPIE 
The papers in this volume were part of the technical conference cited on the cover and title page. Papers were selected and subject to review by the editors and conference program committee. Some conference presentations may not be available for publication. Additional papers and presentation recordings may be available online in the SPIE Digital Library at SPIEDigitallibrary.org.

The papers reflect the work and thoughts of the authors and are published herein as submitted. The publisher is not responsible for the validity of the information or for any outcomes resulting from reliance thereon.

Please use the following format to cite material from these proceedings:

Author(s), "Title of Paper," in Sensing for Agriculture and Food Quality and Safety VIII, edited by Moon S. Kim, Kuanglin Chao, Bryan A. Chin, Proceedings of SPIE Vol. 9864 (SPIE, Bellingham, WA, 2016) Six-Digit Article CID Number.

ISSN: 0277-786X

ISSN: 1996-756X (electronic)

ISBN: 9781510601055

Published by

SPIE

P.O. Box 10, Bellingham, Washington 98227-0010 USA

Telephone +1 3606763290 (Pacific Time) · Fax +1 3606471445

SPIE.org

Copyright (C) 2016, Society of Photo-Optical Instrumentation Engineers.

Copying of material in this book for internal or personal use, or for the internal or personal use of specific clients, beyond the fair use provisions granted by the U.S. Copyright Law is authorized by SPIE subject to payment of copying fees. The Transactional Reporting Service base fee for this volume is $\$ 18.00$ per article (or portion thereof), which should be paid directly to the Copyright Clearance Center (CCC), 222 Rosewood Drive, Danvers, MA 01923. Payment may also be made electronically through CCC Online at copyright.com. Other copying for republication, resale, advertising or promotion, or any form of systematic or multiple reproduction of any material in this book is prohibited except with permission in writing from the publisher. The CCC fee code is 0277-786X/16/\$18.00.

Printed in the United States of America.

Publication of record for individual papers is online in the SPIE Digital Library.

\section{SPIE. DIGITAL}

Paper Numbering: Proceedings of SPIE follow an e-First publication model. A unique citation identifier (CID) number is assigned to each article at the time of publication. Utilization of CIDs allows articles to be fully citable as soon as they are published online, and connects the same identifier to all online and print versions of the publication. SPIE uses a six-digit CID article numbering system structured as follows:

- The first four digits correspond to the SPIE volume number.

- The last two digits indicate publication order within the volume using a Base 36 numbering system employing both numerals and letters. These two-number sets start with $00,01,02,03,04$, $05,06,07,08,09,0 A, 0 B \ldots$ OZ, followed by 10-1Z, 20-2Z, etc. The CID Number appears on each page of the manuscript. 


\title{
Contents
}

\author{
vii Authors \\ ix Conference Committee
}

\section{SESSION 1 PATHOGEN DETECTION}

986405 Active fluid mixing with magnetic microactuators for capture of salmonella [9864-4]

\section{SESSION 2 SPECTRAL SENSING APPLICATIONS I}

986406 Detection of fresh bruises in apples by structured-illumination reflectance imaging [9864-5]

986407 Relationship between shelf-life and optical properties of Yuanhuang pear in the region of 400-1150 nm [9864-6]

986409 Comparative analysis of Worldview-2 and Landsat 8 for coastal saltmarsh mapping accuracy assessment [9864-9]

\section{SESSION 3 RAMAN SPECTROSCOPY AND IMAGING}

9864 OA Detection of metanil yellow contamination in turmeric using FT-Raman and FT-IR spectroscopy [9864-10]

9864 OB Detection of chemical residues in food oil via surface-enhanced Raman spectroscopy [9864-11]

9864 OC Line-scan spatially offset Raman spectroscopy for inspecting subsurface food safety and quality [9864-12]

9864 OD Classification of cucumber green mottle mosaic virus (CGMMV) infected watermelon seeds using Raman spectroscopy [9864-13]

9864 OE Continuous gradient temperature Raman spectroscopy of the long chain polyunsaturated fatty acids docosapentaenoic (DPA, 22:5n-6) and docosahexaenoic (DHA; 22:6n-3) from -100 to $20^{\circ} \mathrm{C}[9864-14]$

\section{SESSION 4 MICROBIAL AND CHEMICAL CONTAMINANT DETECTION}

9864 OF Portable NIR bottled liquid explosive detector (Invited Paper) [9864-15]

$9864 \mathrm{OH}$ Method for detection of a few pathogenic bacteria and determination of live versus dead cells (Best Paper Award) [9864-17] 
$98640 \mathrm{~J} \quad$ Characterization of a new fertilizer during field trials by hyperspectral imaging [9864-19]

9864 OM Hyperspectral imaging system for disease scanning on banana plants [9864-22]

9864 ON Food inspection using hyperspectral imaging and SVDD [9864-23]

SESSION 6 SPECTRAL SENSING APPLICATIONS II

9864 OP Applicability of ion mobility spectrometry for detection of quarantine pests in wood [9864-25]

$98640 Q \quad$ A sequential method for measuring the optical properties of two-layer media with spatially-resolved diffuse reflectance: simulation study [9864-26]

9864 OR Design of an automated cart and mount for a hyperspectral imaging system to be used in produce fields [9864-27]

POSTER SESSION

9864 OT Nondestructive and rapid detection of potato black heart based on machine vision technology [9864-29]

$98640 \mathrm{U} \quad$ Rapid discrimination of main red meat species based on near-infrared hyperspectral imaging technology [9864-30]

9864 OV A portable nondestructive real-time detection system for inspection of pork quality attributes using Vis/NIR spectral technique [9864-31]

9864 OW Development of hand-held nondestructive detection device for assessing meat freshness [9864-32]

9864 OY Raman spectroscopy-based detection of chemical contaminants in food powders [9864-34]

$9864 \mathrm{OZ}$ Whole-surface round object imaging method using line-scan hyperspectral imaging system (Best Paper Award) [9864-35]

986410 MCT-based SWIR hyperspectral imaging system for evaluation of biological samples [9864-36]

986411 Detection of fecal contamination on beef meat surfaces using handheld fluorescence imaging device (HFID) [9864-37]

986412 Alternative soaking media for the FDA procedure in the detection of salmonella from tomatoes and spinach leaf using phage magnetoelastic biosensors [9864-38]

986415 Raman mapping of intact biofilms on stainless steel surfaces [9864-41] 
986416 Identifying fecal matter contamination in produce fields using multispectral reflectance imaging under ambient solar illumination [9864-42]

986417 The effect of the laser wavelength on collinear double pulse laser induced breakdown spectroscopy (DP-LIBS) [9864-43] 
Proc. of SPIE Vol. $9864986401-6$

Downloaded From: https://www.spiedigitallibrary.org/conference-proceedings-of-spie on 26 Apr 2023 Terms of Use: https://www.spiedigitallibrary.org/terms-of-use 


\section{Authors}

Numbers in the index correspond to the last two digits of the six-digit citation identifier (CID) article numbering system used in Proceedings of SPIE. The first four digits reflect the volume number. Base 36 numbering is employed for the last two digits and indicates the order of articles within the volume. Numbers start with 00, 01, 02, 03, 04, 05, 06, 07, 08, 09, OA, OB...0Z, followed by 10-1Z, 20-2Z, etc.

\begin{tabular}{|c|c|}
\hline Alexeev, A., 05 & Kistler, Ross, OR \\
\hline Bae, Abigail, OY & Lee, Hoonsoo, OD, 0Z, 10, 11, 16 \\
\hline Baek, Insuck, OZ, 10 & Lefcourt, Alan M., OR \\
\hline Bal, Abdullah, ON & Levy, L., OP \\
\hline Ballard, M., 05 & Li, Richard, 06 \\
\hline Barbaree, James M., OH, 12 & Lim, Hyoun-Sub, OD \\
\hline Bauchan, Gary L., OE & Lin, Yanqing, 17 \\
\hline Bayona, Oswaldo, OM & Liu, Jing, 17 \\
\hline Binol, Hamidullah, ON & Liu, Yuzhe, $\mathrm{OH}$ \\
\hline Bonifazi, Giuseppe, 0J & Lu, Renfu, 06, OQ \\
\hline Broadhurst, C. Leigh, OE & Lu, Yuzhen, 06 \\
\hline Bulluck, R., OP & Mills, Z., 05 \\
\hline Carey, C., OP & Miyato, Yuji, OF \\
\hline Castro, Rodrigo, $\mathrm{OM}$ & Moon, Sang-Ho, 11 \\
\hline Cevallos, Juan, OM & Mosser, L., OP \\
\hline Chan, Dian, OA & Myers, S. W., OP \\
\hline Chang, Hsing-Chung, 09 & Nguyen, Julie K., OE, 15 \\
\hline Chao, Kuanglin, $\mathrm{OA}, \mathrm{OC}, \mathrm{OE}, \mathrm{OU}, \mathrm{OY}$ & Nou, Xiangwu, 15 \\
\hline Chen, I-Hsuan, $\mathrm{OH}, 12$ & Ochoa, Daniel, OM \\
\hline Chin, Bryan A., OH, 12 & O'Donnell, Colm P., 16 \\
\hline Cho, Byoung-Kwan, OD, $\mathrm{OZ}$ & Oh, Mirae, 11 \\
\hline Cho, Hyunjeong, 11 & Ono, Masaki, OF \\
\hline Criollo, Ronald, $\mathrm{OM}$ & Owen, D., 05 \\
\hline Dhakal, Sagar, OA, OY & Peng, Yankun, OT, OU, OV, OW \\
\hline Diti, Israt Jahan, 09 & Qiao, Lu, OU, OW \\
\hline Du, Songtao, $\mathrm{OH}$ & Qin, Jianwei, OA, OC, OE, OU, OY \\
\hline Erickson, M., 05 & Ralph, Tim, 09 \\
\hline Ervin, A. M., OP & Rao, Xivain, 07 \\
\hline Everard, Colm D., 16 & Rasel, Sikdar M. M., 09 \\
\hline Ewing, K. J., OP & Romero, Dennis, OM \\
\hline Fan, Shuang, 17 & Saintilan, Neil, 09 \\
\hline Fang, Zhenhuan, 07 & Sanghera, J., OP \\
\hline Fu, Xiaping, 07 & Sato-Akaba, Hideo, OF \\
\hline Gadsden, S. Andrew, OR, OZ & Schmidt, Walter F., OA, OE, 15 \\
\hline Garcia Izquierdo, Carlos, 0J & Serranti, Silvia, OJ \\
\hline Gleason, G., OP & Shelton, Daniel R., OE \\
\hline Hanasoge, S., 05 & Suh, Sang-Jin, $\mathrm{OH}$ \\
\hline He, Xueming, 07 & Sun, Hongwei, OV \\
\hline Heighton, Lynne, 15 & Sun, Kexi, OB \\
\hline Hennessey, M. K., OP & Tian, Fang, ОТ \\
\hline Hesketh, P. J., 05 & Trella, Agata, oJ \\
\hline Hong, Seok Min, 10 & Uekawa, Keisuke, OF \\
\hline Horikawa, Shin, $\mathrm{OH}, 12$ & Uslu, Faruk Sukru, ON \\
\hline Hu, Jiajia, 12 & Vargas, German, OM \\
\hline Huang, Qing, OB, 17 & Wang, Aichen, $0 Q$ \\
\hline Ito, Shiori, OF & Wang, Fengen, 12 \\
\hline Itozaki, Hideo, OF & Wang, Qi, 17 \\
\hline Kim, Eun-Kyung, 11 & Wei, Wensong, OT, OW \\
\hline Kim, Moon S., OA, OC, OE, OY, OZ, 10, 11,16 & Wikle, Howard C., $\mathrm{OH}$ \\
\hline
\end{tabular}


Wu, Yuejin, 17

Xie, Lijuan, $0 Q$

$X \cup, J ., 05$

$X u$, Yunfeng, 15

$\mathrm{XU}, \mathrm{Zhuopin}, 17$

Proc. of SPIE Vol. $9864986401-8$

Downloaded From: https://www.spiedigitallibrary.org/conference-proceedings-of-spie on 26 Apr 2023 Terms of Use: https://www.spiedigitallibrary.org/terms-of-use 


\section{Conference Committee}

Symposium Chair

Ming C. Wu, University of California, Berkeley (United States)

Symposium Co-chair

Majid Rabbani, Eastman Kodak Company (United States)

Conference Chairs

Moon S. Kim, USDA Agricultural Research Service (United States)

Kuanglin Chao, USDA Agricultural Research Service (United States)

Bryan A. Chin, Auburn University (United States)

\section{Conference Program Committee}

Arun K. Bhunia, Purdue University (United States)

Suming Chen, National Taiwan University (Taiwan)

Byoung-Kwan Cho, Chungnam National University

(Korea, Republic of)

Stephen R. Delwiche, USDA Agricultural Research Service

(United States)

Ki-Bok Kim, Korea Research Institute of Standards and Science (Korea, Republic of)

Naoshi Kondo, Kyoto University Graduate School of Agriculture (Japan)

Kurt C. Lawrence, USDA Agricultural Research Service (United States)

Kangjin Lee, National Academy of Agricultural Science (Korea, Republic of)

Alan M. Lefcourt, USDA Agricultural Research Service (United States) Changying (Charlie) Li, The University of Georgia (United States)

Renfu Lu, USDA Agricultural Research Service (United States)

Bosoon Park, USDA Agricultural Research Service (United States)

Yankun Peng, China Agricultural University (China)

Yang Tao, University of Maryland, College Park (United States)

Gang Yao, University of Missouri-Columbia (United States)

Haibo Yao, Mississippi State University (United States)

Yibin Ying, Zhejiang University (China)

Seung-Chul Yoon, USDA Agricultural Research Service (United States) 
Session Chairs

1 Pathogen Detection

I-Hsuan Chen, Auburn University (United States)

2 Spectral Sensing Applications I

Mi-Kyung Park, Kyungpook National University (Korea, Republic of)

3 Raman Spectroscopy and Imaging

Renfu Lu, USDA Agricultural Research Service (United States)

4 Microbial and Chemical Contaminant Detection

Byoung-Kwan Cho, Chungnam National University

(Korea, Republic of)

5 Hyperspectral Imaging for Food Safety and Quality

Seung-Chul Yoon, USDA Agricultural Research Service (United States)

6 Spectral Sensing Applications II

Jianwei Qin, USDA Agricultural Research Service (United States) 